\title{
Mechanical Effect of Poller Screw in Metaphyseal Fractures of Tibia Fixed by Locking Intra-Medullary Nail
}

\author{
MOAAZ ABD EL-MONAEM, M.Sc.*; MOHAMED A. OMAR, M.D.** and HANY A. SOLIMAN, M.D.** \\ The Department of Orthopedic Surgery, Shebeen El-Kom Teaching Hospital* and Faculty of Medicine, Al-Azhar University**, \\ Cairo
}

\begin{abstract}
Background: Intramedullary nailing of metaphyseal fractures may be associated with deformity as a result instability after fixation. Our aim was to evaluate the clinical use of Poller screws (blocking screws) as a supplement to stability after fixation with statically locked intramedullary nails of small diameter.
\end{abstract}

Aim of Study: To evaluate the mechanical effect and clinical outcome of poller screw in metaphyseal fractures of tibia fixed by locking intramedullary nail.

Patients and Methods: 15 men and 5 women (20 fractures) aged 19 to 60 (mean, 36.25) years underwent fixation of tibial metaphysis by locking intramedullary nail and poller screw. The mechanisms of injury included motor car accident in thirteen patients, fall from height in two patients, direct trauma in five patients. Radiological and clinical outcome was evaluated.

Results: Twenty patients were followed-up in the outpatient clinic for assessment of fracture healing or the establishment of a nonunion. Union was defined as the healing of at least 3 of 4 cortices on a biplanar radiograph. All the twenty patients $(100 \%)$ achieved union at average time twenty weeks (ranging from 16 to 24 weeks).

Conclusion: Poller (blocking) screws are an important adjunct for intramedullary nailing; aiding fracture reduction at the metaphysis, and offsetting deforming forces that cause malalignment.

Key Words: Poller screw - Fracture fixation - Intramedullary nail - Metaphyseal - Tibial fractures - Treatment.

\section{Introduction}

THE tibia is an important weight bearing bone in the lower limb [1]. The tibia is the most commonly fractured long bone [2]. The tibial medullary canal extends from the cancellous bone of the proximal

Correspondence to: Dr. Moaaz Abd El-Monaem, The Department of Orthopedic Surgery, Faculty of Medicine, Al-Azhar University, Cairo metaphysis to that of the distal metaphysis. The canal of the tibia is widest in diameter in the metaphysis offering the least purchase for fracture reduction with intramedullary nails [3]. An intramedullary nail has become the best treatment of long bone fractures "diaphyseal and selected metaphyseal fractures" which provide good stability with limited soft-tissue dissection [4]. Intramedullary nail stabilization has become the favorable treatment for femoral and tibial shaft fractures, with reported union rates for the femur and the tibia approaching 97\% [5]. Unlike screws and plates, intramedullary fixation has the advantage of loadsharing [6]. Intramedullary nailing is desirable since plate osteosynthesis of the tibia has been shown to have a higher incidence of wound breakdown and infection [7]. Tibial intramedullary nails are still largely inserted through the patellar tendonsplitting or para-patellar tendon approach [8]. Although intramedullary nail has been the best treatment for diaphyseal tibial fractures, its role in the management of fractures occurring at the proximal or distal metaphysis of tibia remains controversial, because high complication rates that mostly refer to unsuccessful reduction and malalignment have been reported [9]. The cause of malalignment has been attributed both to displacing muscular forces and residual instability, to overcome these problems and improve outcomes, many options to the best operative technique have been proposed, such as the poller screws $[\mathbf{1 0 , 1 1 ]}$. The use of poller screws was first defined by Krettek and colleagues. These Poller screws decrease the width of the medullary canal, block the nail, and increase the mechanical stiffness of the bone-implant contact. The mechanical effect of the Poller screw is stabilizing tibial fractures with small proximal or distal fragments with the insertion of small-diameter intramedullary nails $[12,13]$. Stedtfeld et al., demonstrated that 
good axial alignment may be achieved with the nail in the central position and one blocking screw in the short fragment near the fracture on the concave side of the axial deformity [14].

\section{Patients and Methods}

\section{Study design:}

This is a prospective randomized controlled study that was conducted to evaluate the mechanical effect and clinical outcome of poller screw-in metaphyseal fractures of tibia fixed by locking intramedullary nail.

\section{Study location (settings) and duration:}

Orthopedic Department, Al-Zahraa Hospital, Al-Azhar University, Cairo, Egypt.

Orthopedic Department, Shebeen El-Kom Teaching Hospital, Shebeen El-Kom, Menoufia, Egypt.

From October 2019 to April 2020.

\section{Study subject:}

20 patients suffering from metaphyseal tibial fractures including five women and fifteen men were presented to Al-Zahraa Hospital and Shebeen El-Kom Teaching Hospital, M to F ratio was 3:1. The age of the patients was ranging from 19 years to 60 years with a mean age of 36.25 years. The mechanisms of injury included motor car accident in thirteen patients, fall from height in two patients, direct trauma in five patients. Our group of the study included two diabetic patients, two hypertensive patients, two both diabetic and hypertensive patients, and fourteen patients with no history of medical importance. According to Tscherne-Gotzen classification of the state of the soft tissue, it includes four grades: $(\mathrm{C} 0, \mathrm{C} 1, \mathrm{C} 2, \mathrm{C} 3)$. In our study; there were six patients (C0), eight patients (C1), and six patients (C2) Fig. (1) [15].

\section{Inclusion criteria:}

- Distal tibial metadiaphyseal fractures.

- Proximal tibial metadiaphyseal fractures.

- Skeletally mature.

- Above 17 years old.

\section{Exclusion criteria:}

- Proximal and distal tibial articular fractures.

- Open fractures.

- Pathological fractures.

Patients consent:

Written informed consent was obtained from all participants (or relatives) before inclusion in the study, explaining the value of the study, plus the procedures that were commenced.

\section{Ethical consideration:}

- The whole study design was approved by the Ethics Committee, Faculty of Medicine for Girls Al-Azhar University.

- Patients feel free to withdraw from the study at any time without any consequences.

- Collected data was not and will not be used for any other purpose.

\section{Methods:}

The patients were examined clinically to evaluate the soft tissue condition and to exclude any vascular or neurological injuries, radiographs were obtained in the AP and lat. views, taking into consideration the above inclusive and exclusive criteria. Patients were put in the above-knee slab until the time of surgery.

Laboratory investigations include complete blood count, blood sugar, liver and kidney functions, and coagulation profile to assess their general condition. There were two diabetic patients, two hypertensive patients, and two diabetic and hypertensive patients.

\section{Anesthesia:}

Ten patients underwent spinal anesthesia, five patients underwent epidural anesthesia and five patients underwent general anesthesia and all were after the anesthesiologist team recommendations according to the general condition of the patients or the recommendations of the patients themselves.

\section{Operative technique:}

The operation was done in a supine position on a radiolucent fracture table, then sterilizing and draping the limb in a sterile position. A transpatellar approach was used for nail insertion. The starting point was obtained using an awl and guide wire with fluoroscopic guidance Figs. $(2,3)$.

A guide wire passed across the fracture intramedullary with the knee flexed, and then reaming of the medullary canal was performed over the guide wire using flexible reamers until reaching the suitable nail size.

Blocking Screws (BS) were placed through percutaneous wounds either opposite the distal portion of the proximal fracture fragment or the proximal portion of the distal fragment and either medial or lateral to the nail according to the fracture pattern and either before or after the nail insertion. 
Generally, the blocking screw was used on the concave side of the deformity near the fracture line in the short fragment when one screw was used between the cortex and the nail under image intensification. When 2 blocking screws were placed, the second screw was on the convex side of deformity near the end of the nail in the short fragment.

To limit apex anterior angulation, BS was placed posterior to the central axis of the tibia so that the nail would pass anterior to the blocking screw. To limit valgus angulation, BS was placed lateral to the central axis of the tibia so the nail would pass medial to the BS. To limit varus angulation, BS was placed medial to the central axis of the tibia so that the nail would pass lateral to the BS.

After a tibial nail of the appropriate length and diameter was selected, it was advanced gently over the guide wire past the fracture site. Fluoroscopic images confirmed the appropriate alignment of the fracture with the passage of the nail through the fracture site. If the alignment was still unsatisfactory, the nail was temporarily removed and the blocking screw was added then the nail was reinserted again. If the alignment was satisfactory, one or two blocking screws were added while applying manual overcorrection to increase the stability of the bone-implant complex and maintain the alignment. The nails were locked in standard fashion proximally and distally with proximal and distal aiming devices Fig. (4).

\section{Post-operative care:}

- Post-operative X-rays were taken both in PA and Lateral, and fracture reduction was confirmed.

- The patients received post-operative antibiotics and the $1^{\text {st }}$ dressing after three days.

- Joint mobilization of both knee and ankle joints was started on the second postoperative day and partial weight-bearing was allowed for six to eight weeks. Thereafter, weight-bearing was increased based on the absence of pain and a study of the radiographs (appearance of callus) in follow-up visits.

\section{Follow-up:}

Following the removal of sutures ( 2 weeks), patients were seen in the clinic every month until the union was achieved clinically and radiographically and after the union.

\section{Methods of assessment of the result:}

A- Clinical assessment: The clinical examination included physical examination, neurovascular examination and assessment of axial alignment, and functional analysis. The rotational alignment was assessed clinically by checking the relationship of the intercondylar axis with the intermalleolar axis and comparing it with that of the normal side. Functional recovery was assessed using the Olerud-Molander score [16]

Olerud-Molander score of 91 to 100 points was considered excellent, 61-90 points: Good, 31-60 points: Fair and less than 31: Poor (Table 1) [16].

B- Radiological assessment: After clinical examination, true orthogonal anteroposterior and lateral radiographs were taken and evaluated according to the RUST (radiological union score of tibial fractures) system. Four cortices in the tibial lines of the anteroposterior and lateral radiographs were evaluated for the persistence of fracture lines and their visibility in all cortices. Scores of 12 were the highest and 4 the lowest (Table 2) [17-19].

Case examples: Figs. $(5,6)$.

Statistical analysis of data:

Data entry, coding, and analysis were conducted using SPSS, IBM Corp .

Table (1): Olerud and Molander score: Graded out of 100.

\begin{tabular}{lll}
\hline & Situation & Score \\
\hline 1- Pain & None & 25 \\
& When walking on irregular train & 20 \\
& When walking on any outdoor surface & 10 \\
& When walking indoor & 5 \\
& Constant and severe & 0 \\
2- Stiffness & None & 10 \\
& Stiff & 0 \\
3- Swelling & None & 10 \\
& Only in the evening & 5 \\
& Constant & 0 \\
4- Climbing & Not a problem & 10 \\
stairs & Asymmetrically & 5 \\
& Impossible & 0 \\
5- Running & Possible & 5 \\
& Impossible & 0 \\
6- Jumping & Possible & 5 \\
& Impossible & 0 \\
7- Squatting & Possible & 5 \\
& Impossible & 0 \\
8- Walking & None & 10 \\
assistance & Bandage ankle brace & 5 \\
& Cane or crush & 0 \\
9- Work or & Same as before & 20 \\
daily life & Less intensive & 15 \\
activities & Adapted work or part-time work & 10 \\
& Severe & 0 \\
\hline & &
\end{tabular}




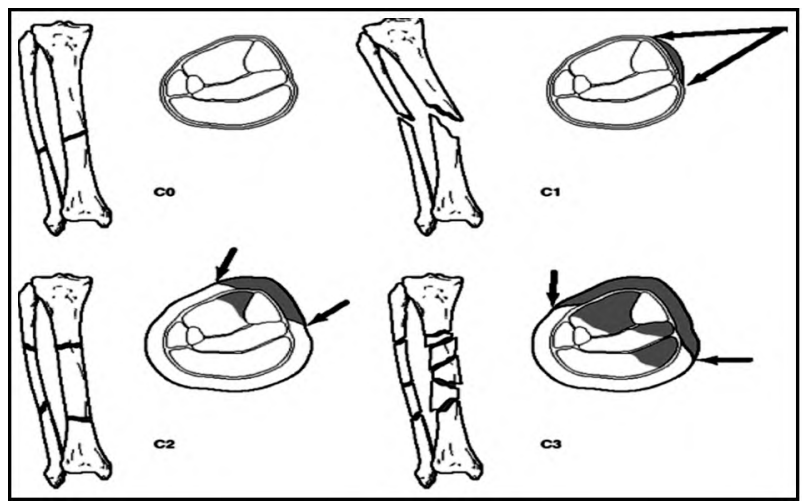

Fig. (1): The Tscherne classification of closed fractures: $\mathrm{C} 0$, simple fracture configuration with little or no soft tissue injury; $\mathrm{C} 1$, superficial abrasion, mild to moderately severe fracture configuration; $\mathrm{C} 2$, deep contamination with local skin or muscle contusion, moderately severe fracture configuration; $\mathrm{C} 3$, extensive contusion or crushing of skin or destruction of muscle, severe fracture (15).
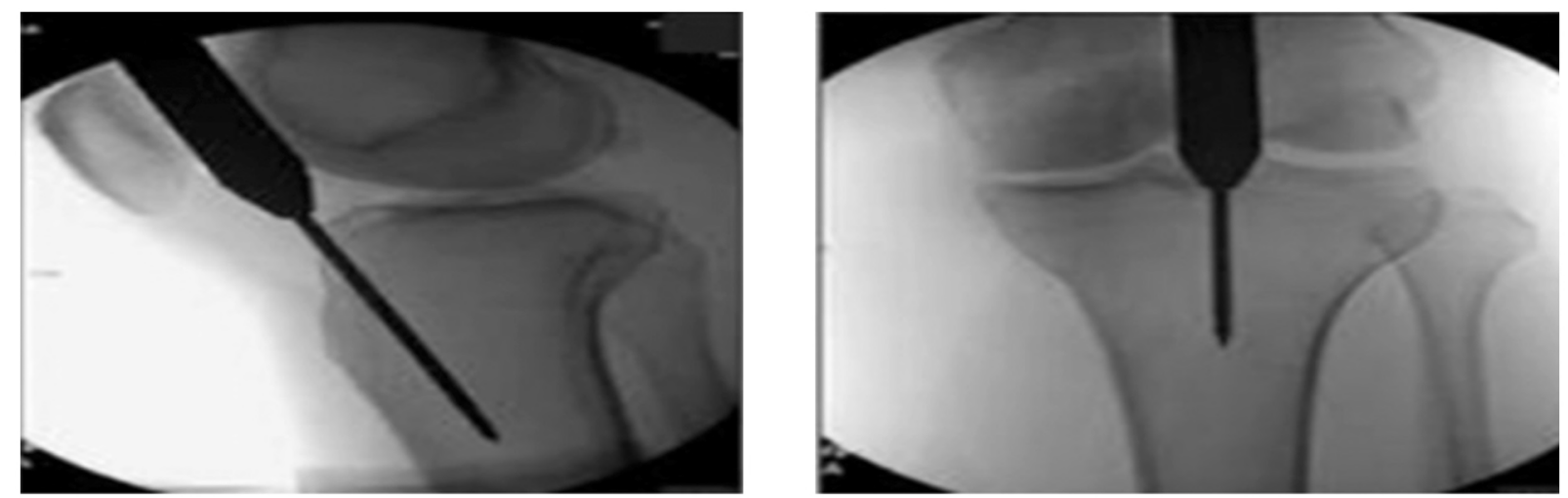

Fig. (3): The starting point was obtained using an awl and guide wire with fluoroscopic guidance in AP and Lat. view.

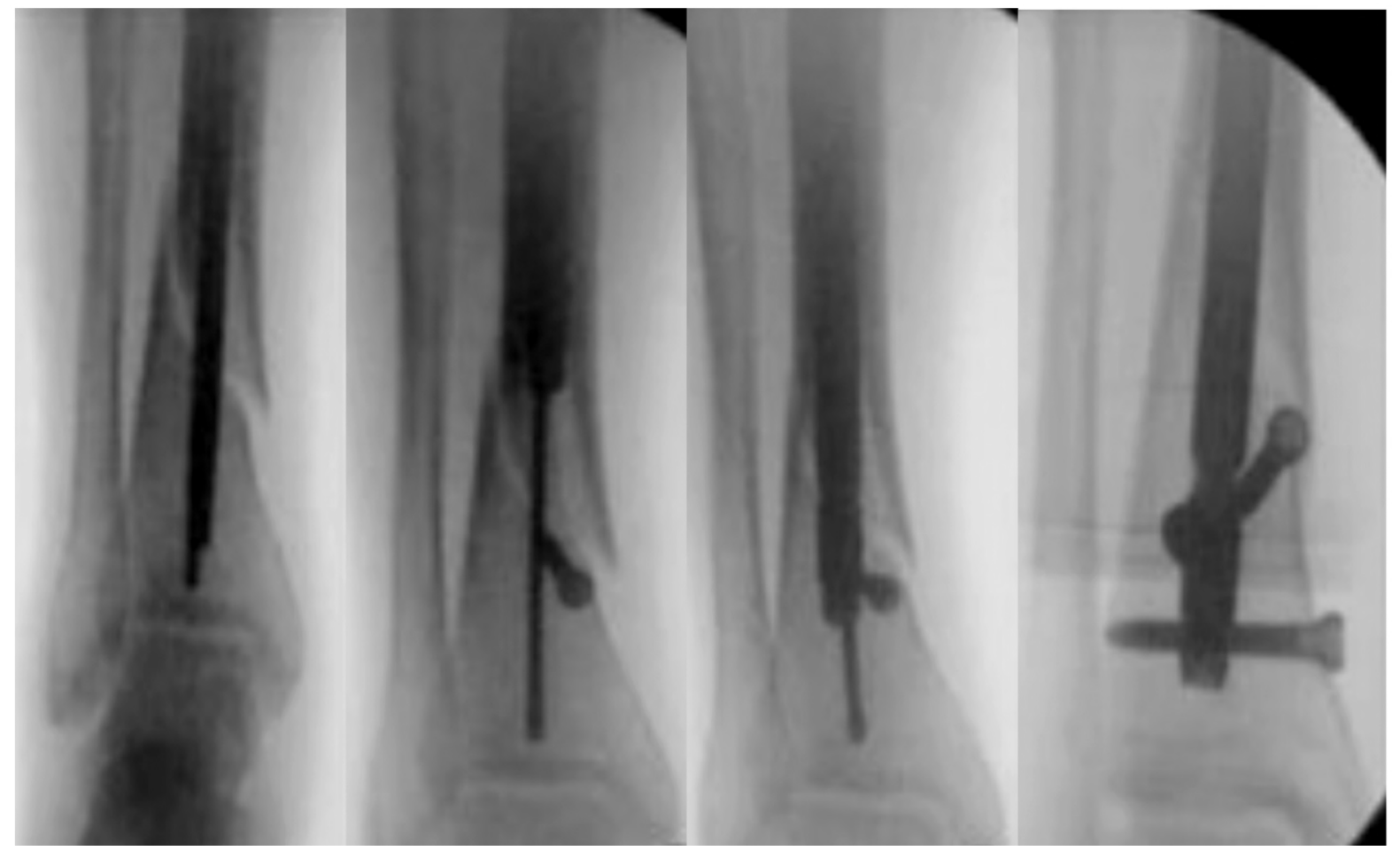

Fig. (4): Reaming and insertion of intramedullary nail and poller screw. 

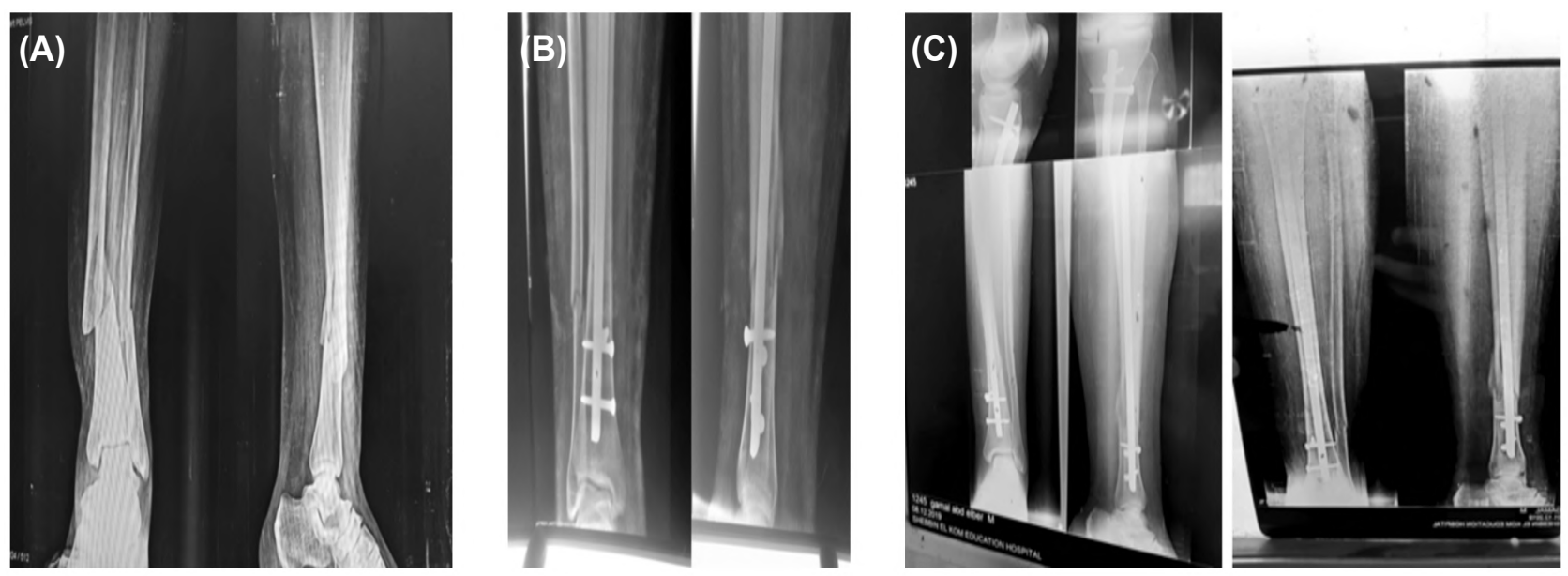

Fig. (5): A- Pre-operative X-ray, B- Post-operative X-ray, C- Follow-up X-ray.
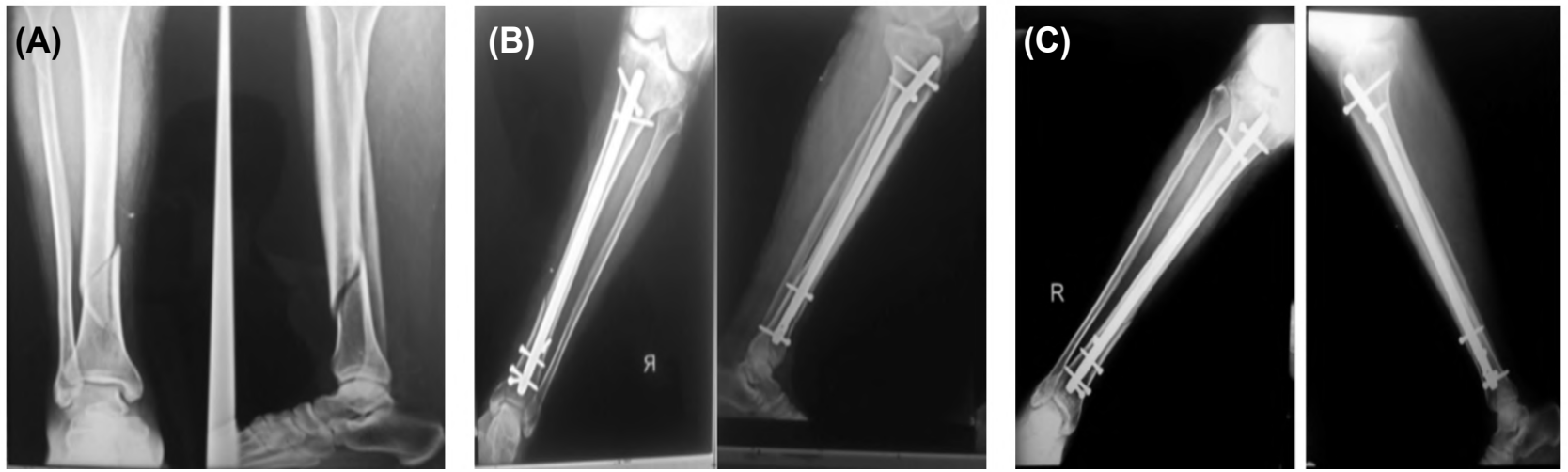

Fig. (6): A- Pre-operative X-ray, B- Post-operative X-ray, C- Follow-up X-ray.

Table (2): Radiographic union scale for Tibial fractures.

\begin{tabular}{cccc}
\hline Cortex & $\begin{array}{c}\text { Fracture line } \\
\text { visible, no } \\
\text { callus }(\text { Score=1) }\end{array}$ & $\begin{array}{c}\text { Visible fracture } \\
\text { line and callus } \\
(\text { Score=2) }\end{array}$ & $\begin{array}{c}\text { No fracture line, } \\
\text { visible callus } \\
\text { (Score=3) }\end{array}$ \\
\hline
\end{tabular}

Anterior

Posterior

Medial

Lateral

\section{Results}

The overall results were studied according to: (Age, sex, medical history, initial deformity, number and site of blocking screws, timing of blocking screws before or after nail insertion, post-operative fracture alignment, fracture healing, alignment, at last, follow-up, complications) all in correlation to Olerud-Molander score.

Our group of studies included thirteen patients below forty years old, five patients from forty to fifty years old, and two patients from fifty to sixty. According to Olerud-Molander score; nine patients had score excellent (seven below forty and two from forty to fifty) and eleven patients had score good (six below forty, three between forty and fifty and two above fifty to sixty) (Table 3 ).
Table (3): Results according to the age group.

\begin{tabular}{ccclc}
\hline Age & \multicolumn{4}{c}{ No. of cases } \\
\hline$<40$ & 13 & 7 & Excellent & 35 \\
& & 6 & Good & 30 \\
$40-50$ & 5 & 2 & Excellent & 10 \\
& & 3 & Good & 15 \\
$50-60$ & 2 & & Good & 10 \\
\hline Total & 20 & & 100 \\
\hline
\end{tabular}

Our group of the study included fifteen men and five women; we found that in the male group; six patients had Olerud-Molander score excellent and nine patients had scored good, while in the female group; three patients had score excellent and two patients had scored good (Table 4).

Table (4): Results according to the sex group.

\begin{tabular}{|c|c|c|c|c|}
\hline \multirow{2}{*}{$\frac{\text { Sex }}{\text { Male }}$} & \multicolumn{4}{|c|}{ No. of cases Olerud Molander Score Percent } \\
\hline & 15 & $\begin{array}{l}6 \\
9\end{array}$ & $\begin{array}{l}\text { Excellent } \\
\text { Good }\end{array}$ & $\begin{array}{l}30 \\
45\end{array}$ \\
\hline Female & 5 & $\begin{array}{l}3 \\
2\end{array}$ & $\begin{array}{l}\text { Excellent } \\
\text { Good }\end{array}$ & $\begin{array}{l}15 \\
10\end{array}$ \\
\hline Total & & & & 100 \\
\hline
\end{tabular}


Our group of the study included two diabetic patients, two hypertensive patients, and two patients both diabetic and hypertensive while the rest of the group had no significant medical history. The two diabetic patients had score good (10\%), the two hypertensive patients; one patient had score excellent (5\%) and the other had score good (5\%), while the two diabetic and hypertensive patients had score good (10\%), while the rest of the group with no medical history; eight patients had score excellent (40\%) and six had score good (30\%) (Table 5).

Our patient group included five patients with varus deformity, all patients had excellent OlerudMolander score. Six patients with lateral translation deformity, five patients had Olerud-Molander score good and one patient had score excellent. Five patients with Valgus deformity, all the five patients had Olerud-Molander score well. Lastly four patients with apex anterior deformity, three patients had Olerud-Molander score excellent and one patient had score good (Table 6).

In the group of the varus deformity, four patients were treated with IMN and one blocking screw medial to the nail from anterior to posterior in the

Table (5): Results according to the medical history of the patients.

\begin{tabular}{lccll}
\hline Medical history & \multicolumn{4}{c}{ No. of cases Olerud Molander Percent } \\
\hline No medical history & 14 & 8 & Excellent & 40 \\
& & 6 & Good & 30 \\
HTN & 2 & 1 & Excellent & 5 \\
& & 1 & Good & 5 \\
DM & 2 & & Good & 10 \\
HTN \& DM & 2 & Good & 10 \\
\hline Total & 20 & & 100 \\
\hline
\end{tabular}

distal fragment and their scores were excellent while one patient was treated with IMN and two blocking screws (one medial proximal and other lateral distal to the nail, both in the distal fragment) and this patient also had score excellent.

In the group of the lateral translation deformity, we used two blocking screws medial to the nail from anterior to posterior in one patient $(5 \%)$ who got score good and we used one blocking screw medial to the nail in five patients $(25 \%)$; of them, one $(5 \%)$ got score excellent and four $(20 \%)$ got score well.

In the group of the five patients with the Valgus deformity, we used one blocking screw lateral to the nail from anterior to posterior in two patients $(10 \%)$, the first patient had a proximal third tibial fracture, we used one blocking screw lateral to the nail in the proximal fragment, while the second patient had a distal third tibial fracture, we used one blocking screw also lateral to the nail but in the distal fragment. Both patients had a score good. We used two blocking screws in three patients $(15 \%)$ (one lateral proximal and the other medial distal to the nail, both in the distal fragment). The three patients got scores good.

Table (6): The initial deformity caused by trauma

\begin{tabular}{|c|c|c|c|}
\hline $\begin{array}{l}\text { Initial } \\
\text { deformity }\end{array}$ & No. of cases & $\begin{array}{l}\text { Olerud Molander } \\
\text { Score }\end{array}$ & Percent \\
\hline Varus & 5 & Excellent & 25 \\
\hline \multirow[t]{2}{*}{ Translation } & 6 & Excellent & 5 \\
\hline & 5 & Good & 25 \\
\hline \multirow[t]{2}{*}{ Apex anterior } & 4 & Excellent & 15 \\
\hline & 1 & Good & 5 \\
\hline Valgus & 5 & Good & 25 \\
\hline Total & 20 & & 100 \\
\hline
\end{tabular}

Table (7): Number and place of blocking screws.

\begin{tabular}{|c|c|c|c|c|c|c|}
\hline \multirow{2}{*}{$\begin{array}{l}\text { Initial } \\
\text { deformity }\end{array}$} & \multicolumn{2}{|c|}{ No. of cases } & \multirow{2}{*}{$\begin{array}{c}\begin{array}{c}\text { Number of } \\
\text { poller screws }\end{array} \\
\begin{array}{l}\text { Single } \\
\text { Double }\end{array}\end{array}$} & \multirow{2}{*}{$\begin{array}{l}\text { Site of poller screws } \\
\text { Medial } \\
1 \text { medial \& } 1 \text { lateral }\end{array}$} & \multirow{2}{*}{$\begin{array}{c}\begin{array}{c}\text { Olerud Molander } \\
\text { Score }\end{array} \\
\text { Excellent } \\
\text { Excellent }\end{array}$} & \multirow{2}{*}{$\begin{array}{l}\text { Percent } \\
\begin{array}{l}20 \\
5\end{array}\end{array}$} \\
\hline & 5 & $\begin{array}{l}4 \\
1\end{array}$ & & & & \\
\hline Translation & 6 & $\begin{array}{ll}5 & 1 \\
& 4 \\
1 & \end{array}$ & $\begin{array}{l}\text { Single } \\
\text { Single } \\
\text { Double }\end{array}$ & $\begin{array}{l}\text { Medial } \\
\text { Medial } \\
2 \text { medial }\end{array}$ & $\begin{array}{l}\text { Excellent } \\
\text { Good } \\
\text { Good }\end{array}$ & $\begin{array}{l}5 \\
20 \\
5\end{array}$ \\
\hline Valgus & 5 & $\begin{array}{l}2 \\
3\end{array}$ & $\begin{array}{l}\text { Single } \\
\text { Double }\end{array}$ & $\begin{array}{l}\text { Lateral } \\
1 \text { medial \& } 1 \text { lateral }\end{array}$ & $\begin{array}{l}\text { Good } \\
\text { Good }\end{array}$ & $\begin{array}{l}10 \\
15\end{array}$ \\
\hline Apex anterior & 4 & $\begin{array}{l}3 \\
1\end{array}$ & $\begin{array}{l}\text { Single } \\
\text { Single }\end{array}$ & $\begin{array}{l}\text { Posterior } \\
\text { Posterior }\end{array}$ & $\begin{array}{l}\text { Excellent } \\
\text { Good }\end{array}$ & $\begin{array}{l}15 \\
5\end{array}$ \\
\hline Total & & & & & & 100 \\
\hline
\end{tabular}


In the group of the four patients with the apex anterior deformity in proximal third tibial fractures, we used in the entire four patients (20\%) one screw posterior to the nail from medial to lateral in the proximal fragment. Three patients $(15 \%)$ had score excellent and one patient (5\%) had score good (Table 7).

We used blocking screws in seven patients before introducing the nail to correct the alignment mainly in patients with apex anterior deformity in proximal third tibial fractures (four patients $20 \%$ ), one patient with varus deformity (5\%), and one patient with lateral translation deformity (5\%) and one patient with Valgus deformity. From these seven patients, five patients had score excellent $(25 \%)$ and two patients had score good (10\%).

We used blocking screws after the insertion of the nail in thirteen patients $(65 \%)$ to improve and maintain the achieved reduction, from these patients; four patients had score excellent (20\%) and nine patients had score good (45\%) (Table 8 ).

Table (8): Timing of blocking screws.

\begin{tabular}{lcclc}
\hline $\begin{array}{l}\text { Timing of } \\
\text { blocking screws }\end{array}$ & No. of cases & $\begin{array}{c}\text { Olerud Molander } \\
\text { Score }\end{array}$ & Percent \\
\hline Before nailing & 7 & 5 & Excellent & 25 \\
& & 2 & Good & 10 \\
After nailing & 13 & 4 & Excellent & 20 \\
& & 9 & Good & 45 \\
\hline Total & 20 & & & 100 \\
\hline
\end{tabular}

AP and Lateral radiographs were obtained for all cases postoperatively and with each follow-up visit. Fracture alignment was determined on these radiographs. AP radiographs were used to determine coronal plane deformity (varus and valgus), and lateral radiographs were used to determine sagittal plane deformity (flexion and extension).

Changes in the alignment were noted. Malalignment was defined as more than $5^{\circ}$ of angular deformity.

Two of the twenty patients had post-operative fracture varus angulation that was less than $5^{\circ}$, they had score excellent, and one patient had postoperative valgus angulation of about $3^{\circ}$ who achieved score good (Table 9).

Twenty patients were followed-up in the outpatient clinic for assessment of fracture healing or the establishment of a nonunion. Union was defined as the healing of at least 3 of 4 cortices on a biplanar radiograph. All the twenty patients $(100 \%)$ achieved union at average time twenty weeks (ranging from 16 to 24 weeks).

Nine patients have RUST score 3 in each cortex i.e. total 12 and excellent Olerud Molander score.

Eleven patients have RUST score 11 and good Olerud Molander score (Table 10):

- Three patients have RUST score 2 in the medial cortex and 3 in other cortices.

- Three patients have RUST score 2 in the lateral cortex and 3 in other cortices.

- Three patients have RUST score 2 in the posterior cortex and 3 in other cortices.

- Two patients have RUST score 2 in the anterior cortex and 3 in other cortices.

Table (9): Post-operative alignment.

\begin{tabular}{lllll}
\hline $\begin{array}{l}\text { Post-operative } \\
\text { alignment }\end{array}$ & No. of cases & $\begin{array}{c}\text { Olerud Molander } \\
\text { Score }\end{array}$ & Percent \\
\hline Neutral & 17 & 7 & Excellent & 35 \\
Varus & 2 & & Good & 50 \\
Valgus & 1 & & Excellent & 10 \\
\hline Total & & & Good & 5 \\
\hline
\end{tabular}

Table (10): Fracture healing according to RUST score.

\begin{tabular}{|c|c|c|c|c|}
\hline \multirow{2}{*}{$\begin{array}{l}\text { Post- } \\
\text { operative } \\
\text { alignment } \\
\text { RUST=12 }\end{array}$} & \multicolumn{2}{|c|}{ No. of cases } & \multirow{2}{*}{$\begin{array}{c}\begin{array}{c}\text { Olerud } \\
\text { Molander } \\
\text { Score }\end{array} \\
\text { Excellent }\end{array}$} & \multirow{2}{*}{$\begin{array}{c}\text { Percent } \\
45\end{array}$} \\
\hline & 9 & & & \\
\hline \multirow[t]{4}{*}{ RUST=11 } & 11 & $\begin{array}{l}3 \text { ( } 2 \text { points in the } \\
\text { medial cortex, } 3 \text { points } \\
\text { in other cortices) }\end{array}$ & Good & 15 \\
\hline & & $\begin{array}{l}3 \text { ( } 2 \text { points in the lateral } \\
\text { cortex, } 3 \text { points in other } \\
\text { cortices) }\end{array}$ & Good & 15 \\
\hline & & $\begin{array}{l}3 \text { ( } 2 \text { points in posterior } \\
\text { cortex, } 3 \text { points in other } \\
\text { cortices) }\end{array}$ & Good & 15 \\
\hline & & $\begin{array}{l}2 \text { ( } 2 \text { points in the } \\
\text { anterior cortex, } 3 \text { points } \\
\text { in other cortices) }\end{array}$ & Good & 10 \\
\hline Total & \multicolumn{2}{|l|}{20} & & 100 \\
\hline
\end{tabular}

\section{Discussion}

The distal and proximal tibial fractures in the metaphysis, stabilized with locking intramedullary nail are associated with a high degree of malalign- 
ment. This has been due to muscular forces which displace the fracture and cause instability [20]

Extra-articular proximal tibial fractures treated with an intramedullary nail will commonly be malreduced in valgus, apex anterior, and have a posterior displacement of the distal fragment [21].

\section{Regarding the preoperative deformity:}

Our patients' group included 5 patients with varus deformity, 6 patients with lateral translation deformity, 5 patients with Valgus deformity, and lastly 4 patients with apex anterior deformity.

In accordance, Kulkarni et al., in 2012 studied 75 cases of proximal tibial fractures who underwent locking intramedullary nail with the use of poller screws pre-operatively, of the 75 cases, 30 cases were varus, 35 cases were valgus and 10 cases were neutral [22].

Also, Shah et al., in 2015 analyzed radiological and clinical outcomes of 60 tibial fractures, 24 proximal third and 36 distal third who underwent treatment with Poller screws. Pre-operatively in 24 cases with proximal tibial fractures, 9 cases were in the neutral position, 9 cases had varus and 6 cases had a valgus deformity. In patients with distal fractures, 15 cases were in the neutral position and 21 cases had a valgus deformity. In total, 15 patients had procurvatum and 21 patients had recurvatum [23].

In a study by Gadegone et al., one hundred and twelve cases with distal tibia fractures were treated with intramedullary nailing. The augmentation was done with Poller screws whenever it was necessary. The unstable distal meta-diaphyseal fractures were stabilized with a Poller screw in 38 cases. Poller screws are used in 23 cases on the medial side, 12 cases on the lateral side, and 3 cases on the posterior side of the nail [24].

\section{Regarding the post-operative alignment:}

In our series cases of metaphysio-diaphyseal fractures treated by an intramedullary nail in combination with Poller screws, there were seventeen cases that showed good alignment with neutral position, while two patients had post-operative fracture varus angulation that was less than $5^{\circ}$, and one patient had post-operative valgus angulation of about $3^{\circ}$.

Similar results were reported in other studies as well. Kulkarni et al., showed the results of seventy-five tibial fractures underwent locking intramedullary nail with poller screws. Postoperatively 74 patients had $<5^{\circ}$ of varus or valgus malalignment and only one has a varus of $+7^{\circ} .65$ cases had no deformity, 7 had a deformity of $<3^{\circ}$, and $3 \mathrm{had}$ a deformity of $4^{\circ}$ to $9^{\circ}$ [22]

Shah et al., in their study of outcomes of 60 tibial fractures showed that; 57 cases had $<5^{\circ}$ valgus or varus deformity 3 cases had $8^{\circ}$ valgus deformity [23].

\section{Regarding fracture healing:}

In our study, all the twenty patients (100\%) achieved union at average time twenty weeks (ranging from 16 to 24 weeks). According to Olerud-Molander score, the outcome has been excellent in 9 patients, good in 11, and poor in none of the patients. Our study showed comparable results with reported series in the literature.

In the study by Sengodan et al., 2014, all the fractures united in a mean period of 11.5 weeks. Karlstrom-Olerud score has been excellent in 14 patients $(70 \%)$, good in 4 patients $(20 \%)$, and fair in 2 patients $(10 \%)(25)$.

In the series by Kulkarni et al., 2012, all 75 patients have bone union eventually. In 69 patients; healing occurred after a mean of 4.2 months. In 5 patients; there was non-union which was united by using a bone graft. One patient was mal-united. Sixty-three cases had recovered a good range of knee motion $\left(0^{\circ}-130^{\circ}\right)$, and the remaining 7 cases sustained flexion of $0^{\circ}$ to $90^{\circ}$. All cases were able to do daily activities with full weight-bearing and without shortening or limping. According to knee rating scale of the Hospital for Special Surgery, the outcome was excellent in 50 cases, good in 14 cases, poor in 3 cases, and failed in 3 cases at month 12 , and remained so after a mean followup of 30.8 months [22].

\section{Regarding the post-operative complications:}

In our study, there was one patient had a new fracture line at the site of placement of the blocking screw so we delayed weight-bearing and applied a back slab for two weeks then started partial weight-bearing. This patient achieved complete union and maintained alignment and according to functional recovery using Olerud-Molander score, he accomplished a good score.

In the study by Kulkarni et al., post-operative complications included anterior knee joint pain in 8 cases, and superficial infections in 4 cases, which was treated with local debridement and use of antibiotic-impregnated beads [22]

In the study by Sengodan et al., 2014, the blocking screw related complications were in one 
case which had a new fracture line while inserting the nail after placement of blocking screw. But the alignment was done and maintained and the fracture united within 8 weeks. Complications which not related to blocking screws were in 2 patients. They had developed an infection and went in for a delayed union of which one required dynamization to achieve union. No neurovascular complications were encountered [25]

\section{Conclusion:}

Poller screw has a good mechanical effect and enhances the clinical outcome metaphyseal fractures of tibia fixed by locking intramedullary nail.

\section{Conflicts of interest:}

There are no conflicts of interest.

\section{References}

1- Gray's anatomy, the anatomical basis of clinical practice, 40 Edition-Churchill livingstone-2008.

2- SCHMIDT A.H., FINKEMEIER C.G. and TORNETTA P. 3rd: Treatment of closed tibial fractures. Instr. Course Lect., 52: 607-22, 2003.

3- KEITH L. MOORE, ARTHUR F. DALLEY and ANNE M.R. AGUR: Moore clinically oriented anatomy, 7 th edition, 2014

4- VALLIER H.A., Le T.T. and BEDI A.: Radiographic and clinical comparisons of distal tibia shaft fractures (4$11 \mathrm{~cm}$ proximal to the plafond): Plating versus intramedullary nailing. J. Orthop. Trauma, 22: 307-11, 2008.

5- BONG M.R., KUMMER F.J., KOVA K.J. and EGOL K.A.: Intramedullary nailing of the lower extremity: Biomechanics and biology. J. Am. Acad. Orthop. Surg., 15: 97-106, 2007.

6- VILMOS V., STEFAN H. and LUKAS L.N.: Intramedullary nailing in fracture treatment: History, science and Kuntscher's revolutionary influence in Vienna, Austria. Injury, (42); S4, S1-S5, 2011.

7- LINDVALL E., SANDERS R., DIPASQUALE T., et al.: Intramedullary nailing versus percutaneous locked plating of extra-articular proximal tibial fractures: Comparison of 56 cases: J. Orthop. Trauma, 23: 485-92, 2009.

8- MAX MORANDI, M.D. and TREVOR BANKA, M.D.: Intramedullary Nailing of Tibial Fractures: Review of Surgical Techniques and Description of a Percutaneous Lateral Suprapatellar Approach, 56: 84-771, 2010.

9- BURC H., DURSUN M., ORHUN H., GURKAN V. and BAYHAN I.: Treatment of adult tibial diaphysis fractures with reamed and locked intramedullary nailing. Acta Orthop. Traumatol. Turc., 43 (1): 7-13, 2009.

10- FREEDMAN E.L. and JOHNSON E.E.: Radiographic analysis of tibial fracture malalignment following intramedullary nailing. Clin. Orthop. Relat. Res., (315): 25-33, 1995.
11- KUBIAK E.N., WIDMER B.J. and HORWITZ D.S.: Extra-articular technique for semiextended tibial nailing. J. Orthop. Trauma, 24 (11): 704-8, 2010.

12-KRETTEK C., RUDOLF J., SCHANDELMAIER P., GUY P., KONEMANN B. and TSCHERNE H.: Unreamed intramedullary nailing of femoral shaft fractures: Operative technique and early clinical experience with the standard locking option. Injury, 27 (4): 233-54, 1996.

13- KRETTEK C., MICLAU T., SCHANDELMAIER P., STEPHAN C., MOHLMANN U. and TSCHERNE H.: The mechanical effect of blocking screws ("Poller screws") in stabilizing tibia fractures with short proximal or distal fragments after insertion of small-diameter intramedullary nails. J. Orthop. Trauma., 13 (8): 550-3, 1999.

14- STEDTFELD H.W., MITTLMEIER T., LANDGRAF P. and EWERT A.: The logic and clinical applications of blocking screws. J. Bone Joint. Surg. Am., 86-A suppl. 2: $17-25,2004$

15- OSTERN H.J. and TSCHERNE H.: Pathophysiology and classification of soft tissue injuries and associated fractures. In: Tscherne H, Gotzen L, editors. Fractures with soft tissue injuries (German), Telger TC, trans. Berlin, Gremany: Springer-Verlag; 1984.

16- OLERUD C. and MOLANDER H.: A scoring scale for symptom evaluation after ankle fracture. Arch. Orthop. Trauma Serg., 103 (3): 190-4, 1984.

17- WHELAN D.B., BHANDARI M., STEPHEN D., KREDER H., McKEE M.D., ZDERO R., et al.: Development of the radiographic union score for tibial fractures for the assessment of tibial fracture healing after intramedullary fixation. J. Trauma, 68: 629-32, 2010.

18- KOOISTRA B.W., DIJKMAN B.G., BUSSE J.W., SPRAGUE S., SCHEMITSCH E.H. and BHANDARI M.: The radiographic union scale in tibial fractures: reliability and validity. J. Orthop. Trauma, 24 Suppl 1: S81-6, 2010.

19- ERMAN ÇEIUÇ, EMIN ALICI and MURAT YESIL: Reliability of the Radiographic Union Score for Tibial Fractures. Acta Orthop. Traumatol. Turc., 48 (5): 533-40, 2014.

20- SEYHAN M., KOCAOGLU B., GERELI A., NALBANTOGLU U. and TURKMEN M.: Treatment for distal tibial fractures with intramedullary nails and blocking screws. Eur. J. Orthop. Surg. Traumatol., 22 (5): 395-401, 2011.

21- HAK D.J.: Intramedullary nailing of proximal third tibial fractures: Techniques to improve reduction. Orthopedics, 34 (7): 532-5, 2011.

22- KULKARNI S.G., VARSHNEYA A., KULKARNI S., et al.: Intramedullary nailing supplemented with Poller screws for proximal tibial fractures. Journal of Orthopaedic Surgery, 20 (3): 307-11, 2012.

23- RAM KEWAL SHAH and SHYAM BABU SHAH: Treatment of Diaphysio-Metaphyseal Fracture of Tibia by Intramedullary Nail in Combination with Pollar Screw. Journal of Bone Reports \& Recommendations, 1: 112-7, 2015. 
24- GADEGONE W., SALPHALE Y. and LOKHANDE V.: Results of Dynamic Interlock Nailing in Distal Tibial Fractures. Surgical Science, 6: 317-26, 2015.
S., KARUNANANDAGANAPATHY S., SUBBIAH SUBRAMANIAN S. and RAJAMANI S.G.: Distal tibial metaphyseal fractures: Does blocking screw extend the indication of intramedullary nailing? ISRN Orthop., 14 $542-9,2014$.

\section{التآثير الميكانيكى للمسمار البولر فى الكسور الكردوسية

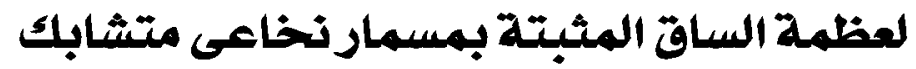

نبذة مختصرة:قد يرتبط تشييت الكسود الكربوسية لعظمة الساق بواسطة مسمار نخاعى متشابك بالتشوه نتيجة علدم الإستقرار بعد التشييت وكان هدفنا تقييم الإستخدام السريرى للمسمار البولر (المسمار الحاجب) كمكمل للإستقرار بعد تثييت الكسود الكربوسية لعظمة الساق بواسطة مسمار نخاعى متشابك.

الهدف من الدراسة: تقييم التَّثير الميكانيكى والنتائج السريرية للمسمار البولر فى الكسود الكربوسية لعظمة الساق المثبتة بمسمار نخاعى متشابك.

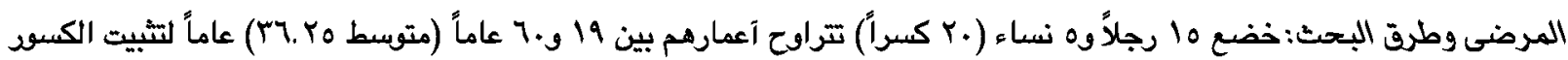

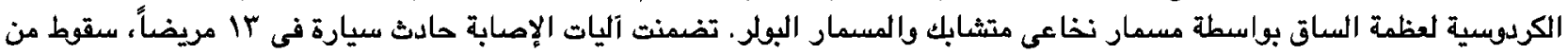

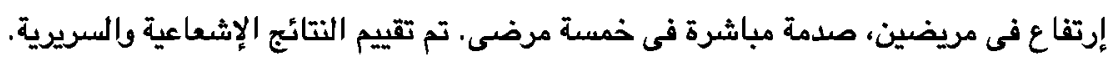

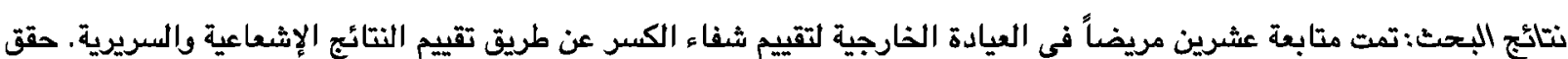

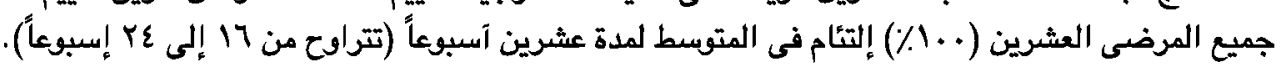

الإستتتاج من الدراسة: يعتبر المسمار البولر (المسمار الحاجب) مساعداً مهماً للحد من التشوه في الكسود الكردوسية لعظمة الساق المثبتة بواسطة مسمار نخاعى متشابك. 